\title{
Effects of EDTA and DTPA on Lead and Zinc Accumulation of Ryegrass*
}

\author{
Hua-Yin Zhao", Li-Jin Lin ${ }^{2}$, Qiao-Lun Yan ${ }^{1}$, Yuan-Xiang Yang ${ }^{1}$, Xue-Mei Zhu ${ }^{1 \#}$, Ji-Rong Shao ${ }^{3}$ \\ ${ }^{1}$ College of Resource and Environment, Sichuan Agricultural University, Chengdu, China; ${ }^{2}$ Ya'an Soil and Water Conservation \\ Monitoring Substation, Ya'an, China; ${ }^{3}$ College of Life Science, Sichuan Agricultural University, Ya'an, China. \\ E-mail: ${ }^{\#}$ zhubroad@163.com
}

Received May 24, 2011; revised July $2^{\text {nd }}, 2011$; accepted August $15^{\text {th }}, 2011$.

\begin{abstract}
The tailing ponds of lead-zinc mines are artificial environment pollution sources, and also important dangerous sources of heavy metal contamination in lead-zinc mining areas. To study the effects of Ethylene Diamine Tetracetic Acid (EDTA) and Diethylene Triamine Penlaacetic Acid (DTPA) on phytoremediation of lead-zinc mining area soil, two chelators (EDTA and DTPA) were used in enrichment plant ryegrass to improve the uptake of $\mathrm{Pb}$ and $\mathrm{Zn}$ from soil. The results showed that when the doses of $0,0.5,1$ and $2 \mathrm{mmol} / \mathrm{kg}$ EDTA and DTPA were used, the biomass of ryegrass (Lolium multiflorum Lam.) and its nutrient ( $N, P, K, C a$ and $M g)$ content increased, whereas EDTA and DTPA with a dose of $4 \mathrm{mmol} / \mathrm{kg}$ decreased the biomass of ryegrass and its nutrient ( $N, P, K, C a$ and $\mathrm{Mg}$ ) content. EDTA and DTPA significantly enhanced the contents of $\mathrm{Zn}$ and $\mathrm{Pb}$ in ryegrass as compared with the control. As for $\mathrm{Pb}$, the content of $\mathrm{Pb}$ in root and shoot reached a maximum of 2730.54 and $2484.42 \mathrm{mg} / \mathrm{kg}$ respectively when the dose of EDTA and DTPA was $2 \mathrm{mmol} / \mathrm{kg}$. In the case of $\mathrm{Zn}$, the content of $\mathrm{Zn}$ in root and shoot reached a maximum of 2428.37 and $2010.43 \mathrm{mg} / \mathrm{kg}$ respectively. The total $\mathrm{Pb}$ and $\mathrm{Zn}$ accumulations and translocation ratio in ryegrass had also been enhanced. The results indicated that EDTA and DTPA had great potential to be used for ryegrass to remedy $\mathrm{Pb}$ and $\mathrm{Zn}$ contamination soil of lead-zinc mining area, but should be used cautiously because of their environmental risks.
\end{abstract}

Keywords: EDTA, DTPA, Enrichment Plant, Ryegrass, Lead and Zinc

\section{Introduction}

With the development of lead-zinc mineral resources, heavy metals were released and transferred into the ecological environment [1], which caused serious environmental problems. The contents of organic matter, nitrogen and phosphorus in the soil around the mine tailing area were reduced to levels that were $20 \%-30 \%$ of those found in normal conditions [2,3]. As a result, it was urgent to apply ecological remediation methods in the lead-zinc mining area.

Recently, phytoremediation has appeared as an alternative reliable $[4,5]$. The use of hyperaccumulator species in continuous phytoextraction processes is limited by the low bioavailability of pollutants to the root uptake [6]. Some studies found that the application of chelating agents showed positive effects on increasing the solubility of heavy metals in soil, thereby enhancing phytoextraction [7-9], and enhancing the amount of bioavailable

*Project supported by Program of Science and Technology Bureau of Sichuan Province, China (No. 2008FZ0180). lead more than 100 times [10,11]. At present, most of the reported hyperaccumulators or accumulators have not had a very good effect on remedying heavy metals because of their small biomass and slow growth $[12,13]$. So, it could be a reliable practice to increase metal bioavailability, uptake and accumulation in the shoots of plants by applying chelator $[9,14-16]$.

Annual ryegrass (Lolium multiflorum Lam.) is one kind of accumulator and graminaceous monocotyledon, and it has a strong regeneration ability and resistance to pests and diseases with its high biomass [17,18]. We aimed to access the influence of EDTA and DTPA on phytoremediation for contaminated soil of lead-zinc mining areas using ryegrass, providing a case of the use and promotion of chelator-induced phytoextraction in contaminated soil.

\section{Materials and Methods}

Annual ryegrass (L. multiflorum Lam.), ethylene diamine tetracetic acid (EDTA) and diethylene triamine penlaace- 
tic acid (DTPA) were selected as experimental plant and chelators. Soil was selected from the lead-zinc mining area of Tangjia Mountain which located in Hanyuan county, Sichuan province, China. The most relevant characteristics of the soil were (mean values) as follows, $\mathrm{pH} 6.83$, organic matter $6.82 \mathrm{~g} / \mathrm{kg}$, total $\mathrm{N} 0.756 \mathrm{~g} / \mathrm{kg}$, total P $0.658 \mathrm{~g} / \mathrm{kg}$, total $\mathrm{K} 17.951 \mathrm{~g} / \mathrm{kg}$, available $\mathrm{N}$ $93.156 \mathrm{mg} / \mathrm{kg}$, available $\mathrm{P} 3.426 \mathrm{mg} / \mathrm{kg}$, available $\mathrm{K}$ $75.221 \mathrm{mg} / \mathrm{kg}$ CEC $5.368 \mathrm{cmol} / \mathrm{kg}$, total $\mathrm{Pb} 2921.32$ $\mathrm{mg} / \mathrm{kg}$, total $\mathrm{Zn} 1841.5 \mathrm{mg} / \mathrm{kg}$, available $\mathrm{Pb} 378.79$ $\mathrm{mg} / \mathrm{kg}$, available $\mathrm{Zn} 287.37 \mathrm{mg} / \mathrm{kg}$.

The experiment was arranged in a randomized block design with two chelators of 5 levels and four replicates per treatment. Five concentrations of DTPA were 0 $\mathrm{mmol} / \mathrm{kg}$ (A0), $0.5 \mathrm{mmol} / \mathrm{kg}$ (A1), $1 \mathrm{mmol} / \mathrm{kg}$ (A2), 2 $\mathrm{mmol} / \mathrm{kg}$ (A3) and $4 \mathrm{mmol} / \mathrm{kg}$ (A4), and EDTA were 0 $\mathrm{mmol} / \mathrm{kg}$ (B0), $0.5 \mathrm{mmol} / \mathrm{kg}$ (B1), $1 \mathrm{mmol} / \mathrm{kg}$ (B2), 2 $\mathrm{mmol} / \mathrm{kg}$ (B3) and $4 \mathrm{mmol} / \mathrm{kg}$ (B4). After sieving $(<5$ $\mathrm{mm}), 1.5$ kilograms of dried soil were stored in plastic pots $(15 \mathrm{~cm} \times 15 \mathrm{~cm})$, and soil samples were mixed with fertilizers containing $100 \mathrm{mg} / \mathrm{kg} \mathrm{N}$ in the form of urea, 80 $\mathrm{mg} / \mathrm{kg} \mathrm{P}$ as $\mathrm{KH}_{2} \mathrm{PO}_{4}$, and $100 \mathrm{mg} / \mathrm{kg} \mathrm{K}$ as $\mathrm{KCl}$. In all treatments, ryegrass was grown and placed in the artificial climate chamber with the environmental conditions, temperature $26^{\circ} \mathrm{C}$ in day and $22^{\circ} \mathrm{C}$ at night, humidity $75 \%$, light intensity $20000 \mathrm{LX}$ and illumination 12 hour per day. Each pot contained 3 seedlings. When the ryegrass had been growing for 2 months, two mixed chelator solutions were added to the soil. Plants were harvested after 14 days of adding chelator solutions and deactivated enzymes in $105^{\circ} \mathrm{C}$, and baked in the oven in $75^{\circ} \mathrm{C}$ until constant weight.

Plant samples were nitrated by $\mathrm{HCl}-\mathrm{HNO}_{3}-\mathrm{HClO}_{4}$, and the contents of $\mathrm{Pb}, \mathrm{Zn}, \mathrm{P}, \mathrm{K}, \mathrm{Mg}$ and $\mathrm{Ca}$ were determined by ICP-AES, and the content of $\mathrm{N}$ was determined by Kjeldahl nitrogen determination. The data was treated and analyzed by Microsoft Excel 2003 and SPSS 13.0.

\section{Results and Analysis}

\subsection{Biomass and Root-shoot Ratio of Ryegrass}

The results showed that, with a single chelator, the biomass of roots and shoots of ryegrass increased at first, and then decreased with the increasing concentrations of the chelator (Table 1), and the application of EDTA at the dose of $2 \mathrm{mmol} / \mathrm{kg}$ produced the maximum biomass of roots and shoots (1.49 and $1.66 \mathrm{~g} /$ plant respectively). When the dose of DTPA was $2 \mathrm{mmol} / \mathrm{kg}$, the maximum biomass of root and shoot were 1.56 and $1.51 \mathrm{~g} / \mathrm{plant}$ respectively. With the combined application of EDTA and DTPA, the trends in change of the biomass were similar to the application of a single chelator . For 2 $\mathrm{mmol} / \mathrm{kg}$ dose of EDTA and DTPA, the maximum biomass of roots and shoots were 2.01 and $1.89 \mathrm{~g} / \mathrm{plant}$ respectively. The root-shoot ratio of ryegrass showed the reverse law of the biomass. Whatever two chelators were used, they both showed significant effects $(P<0.01)$ on

Table 1. The effects of EDTA and DTPA on biomass and root-shoot ratio of ryegrass.

\begin{tabular}{cccc}
\hline Treatments & & Biomass & Root/Shoot \\
\cline { 2 - 3 } A0B0 & Root $(\mathrm{g} / \mathrm{plant})$ & Shoot $(\mathrm{g} / \mathrm{plant})$ & 0.82 \\
A0B1 & $1.10 \mathrm{M}$ & $1.34 \mathrm{P}$ & 0.88 \\
A0B2 & $1.37 \mathrm{I}$ & $1.46 \mathrm{~K}$ & 0.83 \\
A0B3 & $1.21 \mathrm{~K}$ & $1.66 \mathrm{H}$ & 0.90 \\
A0B4 & $1.49 \mathrm{G}$ & $1.36 \mathrm{~N}$ & 0.81 \\
A1B0 & $1.10 \mathrm{M}$ & $1.43 \mathrm{~L}$ & 0.93 \\
A1B1 & $1.33 \mathrm{I}$ & $1.68 \mathrm{G}$ & 0.96 \\
A1B2 & $1.62 \mathrm{E}$ & $1.81 \mathrm{C}$ & 0.99 \\
A1B3 & $1.80 \mathrm{C}$ & $1.77 \mathrm{E}$ & 0.97 \\
A1B4 & $1.71 \mathrm{D}$ & $1.35 \mathrm{O}$ & 0.79 \\
A2B0 & $1.06 \mathrm{~N}$ & $1.46 \mathrm{~K}$ & 0.96 \\
A2B1 & $1.40 \mathrm{H}$ & $1.71 \mathrm{~F}$ & 0.99 \\
A2B2 & $1.70 \mathrm{D}$ & $1.81 \mathrm{C}$ & 1.00 \\
A2B3 & $1.81 \mathrm{C}$ & $1.28 \mathrm{R}$ & 0.78 \\
A2B4 & $1.00 \mathrm{O}$ & $1.87 \mathrm{~B}$ & 1.02 \\
A3B0 & $1.90 \mathrm{~B}$ & $1.51 \mathrm{~J}$ & 1.03 \\
A3B1 & $1.56 \mathrm{~F}$ & $1.87 \mathrm{~B}$ & 1.06 \\
A3B2 & $1.99 \mathrm{~A}$ & $1.78 \mathrm{D}$ & 1.02 \\
A3B3 & $1.81 \mathrm{C}$ & $1.89 \mathrm{~A}$ & 1.06 \\
A3B4 & $2.01 \mathrm{~A}$ & $1.26 \mathrm{~S}$ & 0.76 \\
A4B0 & $0.96 \mathrm{P}$ & $1.38 \mathrm{M}$ & 1.00 \\
A4B1 & $1.38 \mathrm{H}$ & $1.31 \mathrm{Q}$ & 0.96 \\
A4B2 & $1.26 \mathrm{~J}$ & $1.26 \mathrm{~S}$ & 0.94 \\
A4B3 & $1.18 \mathrm{~L}$ & $1.18 \mathrm{~T}$ & 0.91 \\
A4B4 & $1.07 \mathrm{~N}$ & $1.09 \mathrm{U}$ & 0.75 \\
\hline
\end{tabular}

Note: The data followed by uppercase letters indicate the difference at $1 \%$ level, the same as following tables. 
the biomass of root and shoot of ryegrass.

\subsection{Pb Content in Ryegrass Plant}

With the increased EDTA dose, Pb content in the roots of ryegrass increased before a dose of $2 \mathrm{mmol} / \mathrm{kg}$, and decreased when a dose of $4 \mathrm{mmol} / \mathrm{kg}$ was used (Figure 1). DTPA had approximately the same effects on $\mathrm{Pb}$ content in roots. When the dose of EDTA and DTPA was 2 $\mathrm{mmol} / \mathrm{kg}, \mathrm{Pb}$ content in roots reached the maximum of $2730.54 \mathrm{mg} / \mathrm{kg}$, and it was 3.15 times higher than the control. The results also showed that EDTA increased $\mathrm{Pb}$ content more than DTPA did with the same dose. Both chelators showed significant effects $(P<0.01)$ on $\mathrm{Pb}$ content in roots.

EDTA and DTPA had approximately the same effect on the $\mathrm{Pb}$ content in shoots of ryegrass (Figure 2). $\mathrm{Pb}$ content in shoots reached the maximum of 2484.42 $\mathrm{mg} / \mathrm{kg}$, which was 2.15 times greater than the control, when the dose of EDTA and DTPA was $2 \mathrm{mmol} / \mathrm{kg}$. EDTA enhanced $\mathrm{Pb}$ content in shoots more than DTPA did with the same dose. Both chelators showed significant effects $(P<0.01)$ on $\mathrm{Pb}$ content in shoots.

\subsection{Zn Content in Ryegrass Plant}

$\mathrm{Zn}$ content in the roots of ryegrass had the same variation with the doses of EDTA and DTPA increasing (Figure 3). When the dose of EDTA and DTPA was $4 \mathrm{mmol} / \mathrm{kg}$, $\mathrm{Zn}$ content in roots reached the maximum of 2428.37 $\mathrm{mg} / \mathrm{kg}$, and it was 9.82 times greater than the control. EDTA enhanced Zn content in shoots more than DTPA at the same dose. Both chelators showed significant effects $(P<0.01)$ on $\mathrm{Zn}$ content in root.

EDTA and DTPA had approximately the same effect on the $\mathrm{Zn}$ content in shoots of ryegrass (Figure 4). When the dose of EDTA and DTPA was $4 \mathrm{mmol} / \mathrm{kg}$, Zn content in shoots reached the maximum of $2010.43 \mathrm{mg} / \mathrm{kg}$, and it was 5.14 times higher than the control. With the same dose, EDTA enhanced $\mathrm{Zn}$ content in shoots more than DTPA did. Both chelators showed significant effects $(P$ $<0.01$ ) on $\mathrm{Zn}$ content in shoot.

\subsection{The Correlation between DTPA/EDTA and $\mathrm{Pb}$ and $\mathrm{Zn}$ Content in Ryegrass}

The results of partial-correlation analysis showed that DTPA and EDTA didn't significantly correlate with $\mathrm{Pb}$ content in roots but did significantly correlate with $\mathrm{Pb}$ content in shoots (Table 2). The correlation between DTPA/EDTA and $\mathrm{Zn}$ content in roots and shoots were significant. The results indicated that two chelators had collaborative effects on $\mathrm{Zn}$ content in ryegrass plants.

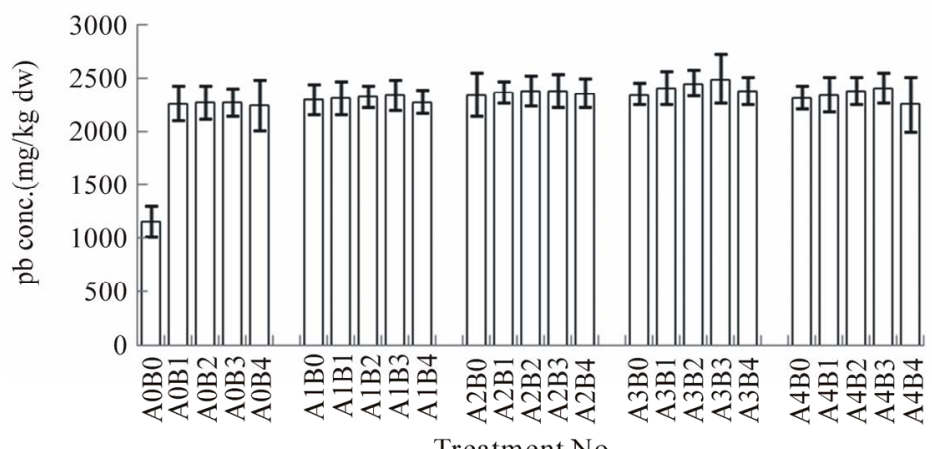

Figure 1. The effects of DTPA and EDTA on Pb content in the roots.

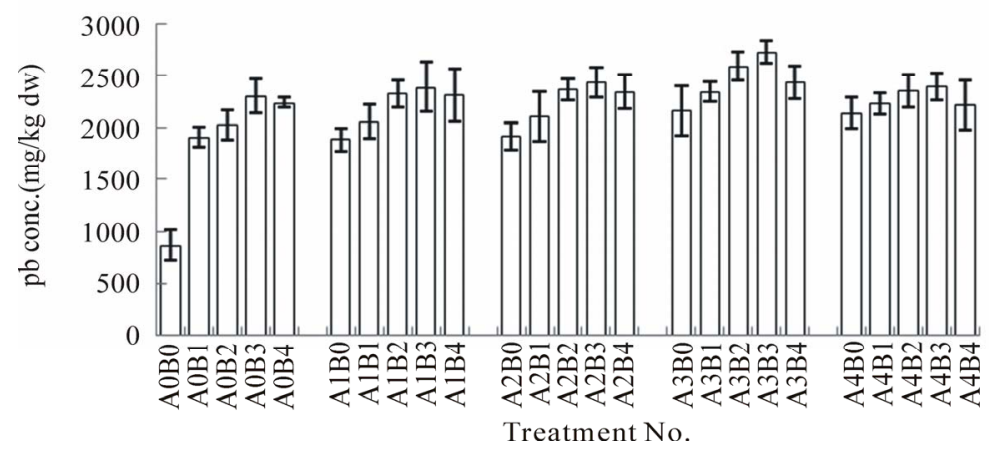

Figure 2. The effects of DTPA and EDTA on Pb content in the shoots. 


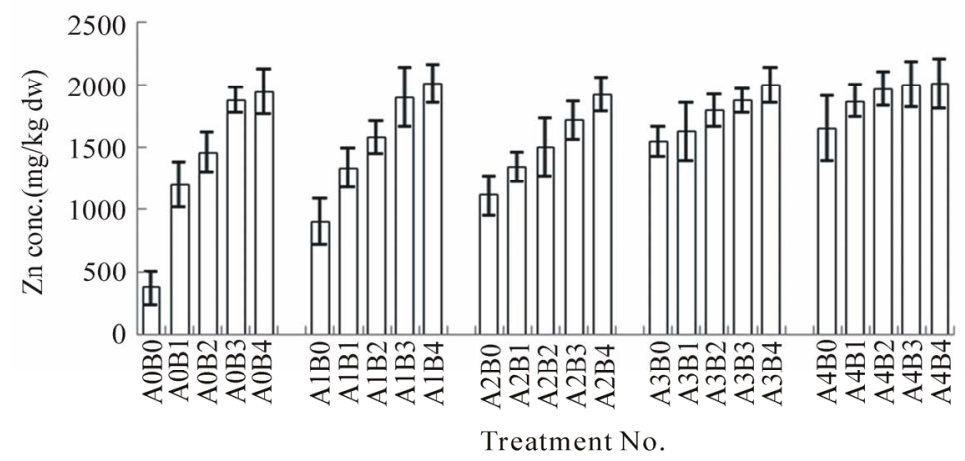

Figure 3. The effects of DTPA and EDTA on Zn content in the roots.

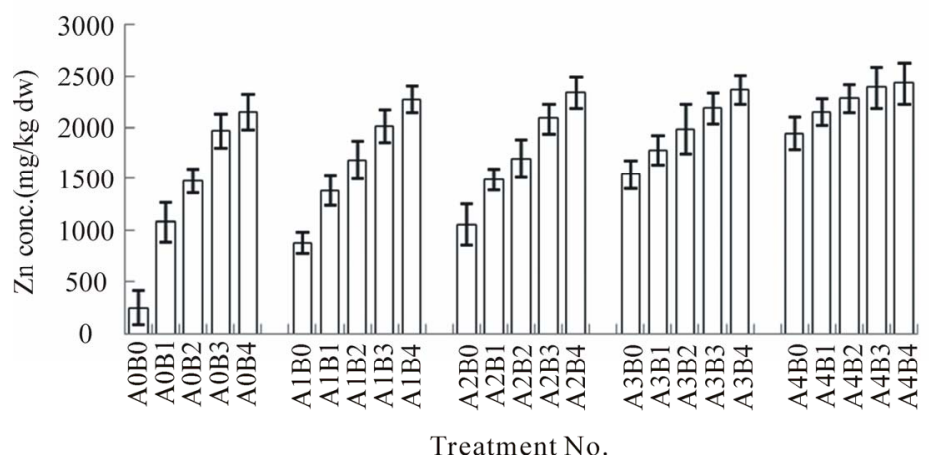

Figure 4. The effects of DTPA and EDTA on Zn content in the shoots.

Table 2. The partial-correlation coefficients of chelators and $\mathrm{Pb} / \mathrm{Zn}$ content in ryegrass plant.

\begin{tabular}{|c|c|c|c|c|}
\hline \multirow{2}{*}{ Chelators } & \multicolumn{2}{|r|}{$\mathrm{Pb}$} & \multicolumn{2}{|r|}{$\mathrm{Zn}$} \\
\hline & Root & Shoot & Root & Shoot \\
\hline EDTA & 0.501 & $0.781^{* *}$ & $0.648^{*}$ & $0.814 * *$ \\
\hline DTPA & 0.421 & $0.706 *$ & $0.801 * *$ & $0.775^{* *}$ \\
\hline
\end{tabular}

Note: $\mathrm{n}=9, \mathrm{r} 0.05=0.632, \mathrm{r} 0.01=0.765, *$ and $* *$ showed the significant levels of $5 \%$ and $1 \%$, respectively.

\subsection{Total $\mathbf{P b}$ and $\mathrm{Zn}$ Accumulation in Ryegrass Plants}

DTPA and EDTA enhanced total $\mathrm{Pb}$ and $\mathrm{Zn}$ accumulation in roots and shoots compared with the control (Table 3). With the increase of one chelator dose, the total $\mathrm{Pb}$ and $\mathrm{Zn}$ accumulation in root and shoot increased at first and decreased at last. The maximum of total $\mathrm{Pb}$ and $\mathrm{Zn}$ accumulation in roots were 4.99 and $3.77 \mathrm{mg} /$ plant respectively, and the maximum of $\mathrm{Pb}$ and $\mathrm{Zn}$ accumulation in shoots were 5.16 and $4.38 \mathrm{mg} /$ plant respectively. The results showed that EDTA and DTPA had significant effects $(P<0.01)$ on the total $\mathrm{Pb}$ and $\mathrm{Zn}$ accumulation in ryegrass plants. Compared with the control, most of the $\mathrm{Pb}$ translocation ratios were enhanced, and all of the $\mathrm{Zn}$ translocation ratios were enhanced. This showed that DTPA and EDTA could promote transfer of $\mathrm{Pb}$ and
$\mathrm{Zn}$ from roots to shoots.

\subsection{Nutrients Contents in Ryegrass Plants}

DTPA and EDTA enhanced the nutrient (N, P, K, Ca and $\mathrm{Mg}$ ) contents in ryegrass plants compared with the control (Table 4). The nutrient contents increased at first and decreased at last when the dose of one chelator increased. The results showed that EDTA and DTPA had significant effects $(P<0.01)$ on the nutrient contents in ryegrass plants. This indicated that DTPA and EDTA could enhance the absorption of nutritional elements from soil to promote the growth of ryegrass plants.

\section{Discussion}

Previous studies found that in a certain range of concentrations, EDTA strongly inhibited plant growth [19]. In this paper, with increased EDTA and DTPA doses, the biomass in roots and shoots of ryegrass increased at first and decreased at last, and the nutrient $(\mathrm{N}, \mathrm{P}, \mathrm{K}, \mathrm{Ca}$ and $\mathrm{Mg}$ ) contents of ryegrass plants increased compared with the control, which could be due to the active effects of chelators on soil nutrients [20,21]. Meanwhile, EDTA may stimulate the heavy metal extraction from the soil [22], and reduced biological toxicityof heavy metals [23]. When the dose of EDTA and DTPA was $4 \mathrm{mmol} / \mathrm{kg}$, the biomass in roots and shoots decreased. This could be due 
Table 3. The effects of DTPA and EDTA on total $\mathrm{Pb}$ and $\mathrm{Zn}$ accumulation in ryegrass plant.

\begin{tabular}{|c|c|c|c|c|c|c|}
\hline \multirow{2}{*}{ Treatments } & \multicolumn{2}{|c|}{ Root } & \multicolumn{2}{|c|}{ Shoot } & \multicolumn{2}{|c|}{ Translocation ratio } \\
\hline & $\mathrm{Pb}$ (mg/plant) & $\mathrm{Zn}$ (mg/plant) & $\mathrm{Pb}$ (mg/plant) & Zn (mg/plant) & $\mathrm{Pb}(\%)$ & $\mathrm{Zn}(\%)$ \\
\hline A0B0 & $1.27 \mathrm{O}$ & $0.41 \mathrm{~J}$ & $1.16 \mathrm{~K}$ & $0.33 \mathrm{~K}$ & 47.72 & 44.86 \\
\hline $\mathrm{A} 0 \mathrm{~B} 1$ & 3.09GHIJ & $1.64 \mathrm{GH}$ & $2.96 \mathrm{GHI}$ & $1.68 \mathrm{~J}$ & 48.93 & 50.58 \\
\hline A0B2 & 2.74IJKLM & $1.77 \mathrm{GH}$ & $2.96 \mathrm{GHI}$ & $2.16 \mathrm{I}$ & 51.95 & 55.06 \\
\hline A0B3 & $3.38 \mathrm{FGH}$ & $2.80 \mathrm{C}$ & $3.83 \mathrm{D}$ & 3.27BCDE & 53.09 & 53.89 \\
\hline A0B4 & $2.46 \mathrm{KLM}$ & $2.14 \mathrm{EF}$ & $3.05 \mathrm{GH}$ & 2.92DEFG & 55.27 & 57.74 \\
\hline $\mathrm{A} 1 \mathrm{~B} 0$ & 3.05GHIJK & $1.20 \mathrm{I}$ & $2.69 \mathrm{IJ}$ & $1.26 \mathrm{~J}$ & 46.89 & 51.18 \\
\hline $\mathrm{A} 1 \mathrm{~B} 1$ & $3.74 \mathrm{DEF}$ & $2.16 \mathrm{EF}$ & $3.46 \mathrm{EF}$ & $2.33 \mathrm{HI}$ & 48.05 & 51.83 \\
\hline A1B2 & 4.17BCDE & $2.84 \mathrm{C}$ & $4.20 \mathrm{C}$ & 3.05CDEFG & 50.19 & 51.76 \\
\hline A1B3 & $3.99 \mathrm{CDE}$ & $3.25 \mathrm{~B}$ & $4.23 \mathrm{C}$ & $3.56 \mathrm{~B}$ & 51.42 & 52.27 \\
\hline A1B4 & $2.40 \mathrm{LMN}$ & $2.13 \mathrm{EF}$ & $3.12 \mathrm{GH}$ & 3.07CDEF & 56.5 & 59.04 \\
\hline $\mathrm{A} 2 \mathrm{~B} 0$ & 3.27FGHI & $1.55 \mathrm{H}$ & $2.80 \mathrm{HI}$ & $1.55 \mathrm{~J}$ & 46.15 & 49.99 \\
\hline $\mathrm{A} 2 \mathrm{~B} 1$ & $4.01 \mathrm{CDE}$ & $2.28 \mathrm{EF}$ & $3.60 \mathrm{DE}$ & $2.56 \mathrm{GHI}$ & 47.3 & 52.85 \\
\hline $\mathrm{A} 2 \mathrm{~B} 2$ & 4.29BCD & $2.72 \mathrm{CD}$ & $4.29 \mathrm{C}$ & $3.08 \mathrm{DEF}$ & 49.98 & 53.14 \\
\hline $\mathrm{A} 2 \mathrm{~B} 3$ & $2.37 \mathrm{LMN}$ & $1.71 \mathrm{GH}$ & $3.11 \mathrm{GH}$ & 2.67FGH & 56.74 & 60.91 \\
\hline $\mathrm{A} 2 \mathrm{~B} 4$ & 4.47ABC & $3.66 \mathrm{~A}$ & $4.38 \mathrm{BC}$ & $4.38 \mathrm{~A}$ & 49.5 & 54.49 \\
\hline $\mathrm{A} 3 \mathrm{~B} 0$ & 3.65EFG & $2.40 \mathrm{DE}$ & $3.27 \mathrm{FG}$ & $2.33 \mathrm{HI}$ & 47.24 & 49.21 \\
\hline $\mathrm{A} 3 \mathrm{~B} 1$ & $4.77 \mathrm{AB}$ & $3.23 \mathrm{~B}$ & $4.38 \mathrm{BC}$ & 3.33BCD & 47.88 & 50.77 \\
\hline A3B2 & $4.42 \mathrm{ABC}$ & $3.25 \mathrm{FB}$ & $4.61 \mathrm{~B}$ & $3.53 \mathrm{BC}$ & 51.05 & 52.06 \\
\hline A3B3 & $4.99 \mathrm{~A}$ & $3.77 \mathrm{~A}$ & $5.16 \mathrm{~A}$ & $4.13 \mathrm{~A}$ & 50.82 & 52.32 \\
\hline A3B4 & $2.28 \mathrm{MN}$ & $1.92 \mathrm{FG}$ & $3.07 \mathrm{GH}$ & 2.98DEFG & 57.4 & 60.79 \\
\hline A4B0 & 3.19FGHI & $2.27 \mathrm{EF}$ & $2.95 \mathrm{HI}$ & $2.68 \mathrm{FGH}$ & 48.01 & 54.1 \\
\hline A4B1 & 2.95HIJKL & $2.35 \mathrm{E}$ & $2.92 \mathrm{HI}$ & 2.81EFGH & 49.73 & 54.43 \\
\hline A4B2 & 2.80HIJKLM & $2.32 \mathrm{E}$ & $2.97 \mathrm{GHI}$ & 2.87DEFG & 51.44 & 55.29 \\
\hline A4B3 & 2.57JKLM & $2.14 \mathrm{EF}$ & $2.83 \mathrm{HI}$ & 2.82EFGH & 52.43 & 56.8 \\
\hline A4B4 & $1.84 \mathrm{~N}$ & $1.65 \mathrm{GH}$ & $2.42 \mathrm{~J}$ & $2.65 \mathrm{FGH}$ & 56.77 & 61.62 \\
\hline
\end{tabular}

Note: Translocation ratio $(\%)=\mathrm{Pb}(\mathrm{Zn})$ accumulation in shoot $/ \mathrm{Pb}(\mathrm{Zn})$ accumulation in root $\times 100 \%$.

Table 4. The effects of EDTA and DTPA on nutrients contents of ryegrass plant.

\begin{tabular}{|c|c|c|c|c|c|}
\hline Treatments & $\mathrm{N}(\mathrm{mg} / \mathrm{g})$ & $\mathrm{P}(\mathrm{mg} / \mathrm{g})$ & $\mathrm{K}(\mathrm{mg} / \mathrm{g})$ & $\mathrm{Ca}(\mathrm{mg} / \mathrm{g})$ & $\mathrm{Mg}(\mathrm{mg} / \mathrm{g})$ \\
\hline A0B0 & 13.2P & $4.8 \mathrm{~N}$ & $20.9 \mathrm{~W}$ & $4.0 \mathrm{M}$ & $1.0 \mathrm{~F}$ \\
\hline A0B1 & $19.8 \mathrm{~N}$ & $5.6 \mathrm{~K}$ & $28.7 \mathrm{U}$ & $4.8 \mathrm{~J}$ & $1.3 \mathrm{E}$ \\
\hline $\mathrm{A} 0 \mathrm{~B} 2$ & $24.7 \mathrm{~L}$ & $6.0 \mathrm{I}$ & $36.1 \mathrm{Q}$ & $5.0 \mathrm{H}$ & $1.4 \mathrm{D}$ \\
\hline A0B3 & 31.6ED & $6.4 \mathrm{~F}$ & $41.4 \mathrm{~L}$ & $5.6 \mathrm{D}$ & $1.5 \mathrm{C}$ \\
\hline A0B4 & $32.7 \mathrm{~A}$ & $6.6 \mathrm{D}$ & $45.7 \mathrm{E}$ & $5.8 \mathrm{~B}$ & $1.7 \mathrm{~A}$ \\
\hline A1B0 & $17.4 \mathrm{O}$ & $5.1 \mathrm{M}$ & $26.6 \mathrm{~V}$ & $4.6 \mathrm{~L}$ & $1.3 \mathrm{E}$ \\
\hline A1B1 & $21.6 \mathrm{M}$ & $5.8 \mathrm{~J}$ & $30.8 \mathrm{~S}$ & $4.9 \mathrm{I}$ & $1.4 \mathrm{D}$ \\
\hline A1B2 & $26.5 \mathrm{~J}$ & $6.2 \mathrm{H}$ & $38.7 \mathrm{O}$ & $5.4 \mathrm{E}$ & $1.5 \mathrm{C}$ \\
\hline A1B3 & $32.0 \mathrm{CD}$ & $6.5 \mathrm{E}$ & $42.1 \mathrm{~K}$ & $5.7 \mathrm{C}$ & $1.6 \mathrm{~B}$ \\
\hline A1B4 & $32.8 \mathrm{~A}$ & $6.8 \mathrm{~B}$ & $46.8 \mathrm{~B}$ & $5.9 \mathrm{~A}$ & $1.7 \mathrm{~A}$ \\
\hline $\mathrm{A} 2 \mathrm{~B} 0$ & $21.5 \mathrm{M}$ & $5.4 \mathrm{~L}$ & $30.6 \mathrm{~T}$ & $4.7 \mathrm{~K}$ & $1.4 \mathrm{D}$ \\
\hline $\mathrm{A} 2 \mathrm{~B} 1$ & $25.7 \mathrm{~K}$ & $6.0 \mathrm{I}$ & $36.2 \mathrm{P}$ & $5.3 \mathrm{~F}$ & $1.5 \mathrm{C}$ \\
\hline $\mathrm{A} 2 \mathrm{~B} 2$ & $30.1 \mathrm{G}$ & $6.4 \mathrm{~F}$ & $40.1 \mathrm{M}$ & $5.6 \mathrm{D}$ & $1.6 \mathrm{~B}$ \\
\hline $\mathrm{A} 2 \mathrm{~B} 3$ & $32.6 \mathrm{AB}$ & $6.8 \mathrm{~B}$ & $44.7 \mathrm{G}$ & $5.8 \mathrm{~B}$ & $1.7 \mathrm{~A}$ \\
\hline $\mathrm{A} 2 \mathrm{~B} 4$ & $32.8 \mathrm{~A}$ & $7.0 \mathrm{~A}$ & $47.0 \mathrm{~A}$ & $5.9 \mathrm{~A}$ & $1.7 \mathrm{~A}$ \\
\hline $\mathrm{A} 3 \mathrm{~B} 0$ & $27.4 \mathrm{I}$ & $6.0 \mathrm{I}$ & $34.2 \mathrm{R}$ & 4.9I & $1.5 \mathrm{C}$ \\
\hline A3B1 & $29.1 \mathrm{H}$ & $6.3 \mathrm{G}$ & 38.70 & $5.4 \mathrm{E}$ & $1.6 \mathrm{~B}$ \\
\hline $\mathrm{A} 3 \mathrm{~B} 2$ & $31.1 \mathrm{~F}$ & $6.6 \mathrm{D}$ & $42.6 \mathrm{~J}$ & $5.7 \mathrm{C}$ & $1.7 \mathrm{~A}$ \\
\hline A3B3 & $32.8 \mathrm{~A}$ & $7.0 \mathrm{~A}$ & $46.4 \mathrm{C}$ & $5.9 \mathrm{~A}$ & $1.7 \mathrm{~A}$ \\
\hline A3B4 & $32.7 \mathrm{~A}$ & $6.8 \mathrm{~B}$ & $46.0 \mathrm{D}$ & $5.6 \mathrm{D}$ & $1.6 \mathrm{~B}$ \\
\hline $\mathrm{A} 4 \mathrm{~B} 0$ & $31.2 \mathrm{EF}$ & $6.2 \mathrm{H}$ & $36.1 Q$ & $5.1 \mathrm{G}$ & $1.6 \mathrm{~B}$ \\
\hline A4B1 & $31.8 \mathrm{CD}$ & $6.4 \mathrm{~F}$ & $39.9 \mathrm{~N}$ & $5.6 \mathrm{D}$ & $1.7 \mathrm{~A}$ \\
\hline A4B2 & $32.2 \mathrm{BC}$ & $6.8 \mathrm{~B}$ & $43.2 \mathrm{I}$ & $5.8 \mathrm{~B}$ & $1.6 \mathrm{~B}$ \\
\hline A4B3 & $32.6 \mathrm{AB}$ & $6.7 \mathrm{C}$ & $44.8 \mathrm{~F}$ & $5.6 \mathrm{D}$ & $1.5 \mathrm{C}$ \\
\hline A4B4 & $32.1 \mathrm{C}$ & $6.5 \mathrm{E}$ & $43.6 \mathrm{H}$ & $5.4 \mathrm{E}$ & $1.5 \mathrm{C}$ \\
\hline
\end{tabular}


to the biological toxicity of free chelators as well as the active effects of chelators on heavy metals [24,25]. Also, the trend of the root-shoot ratio indicated that the ecological adaptability of ryegrass plants had gradually increased.

Some scholars found that $60 \%$ of lead in soil was activated when $15 \mathrm{mmol} / \mathrm{kg}$ EDTA was added to acidic soil (pH 5.5). As EDTA had oxygen atoms with four electron pairs and nitrogen atoms with 2 electron pairs, it mainly existed in soil in the form of $\mathrm{H}_{2}[\text { EDTA }]^{2-}$, and in this acidity range, heavy metal ions mainly existed in the form of bivalent as well. So, EDTA and heavy metal ions could form stable chelates [26,27]. DTPA and EDTA of organic acid ligands had a strong ability of chelation with the change of ligand and heavy metal elements, DTPA played a more stable effect on chelating with lead and zinc than that of EDTA [28]. Blaylock [29] found that DTPA and EDTA could enhance $\mathrm{Pb}$ and $\mathrm{Cd}$ accumulation in shoot of Brassiajuncea (1.6\% and 1.0\% respectively). $\mathrm{Xu}$ [30] showed that EDTA enhanced $\mathrm{Zn}$ accumulation in root and shoot of vetiver grass more than $7.3 \%$ and $37.4 \%$. Combining with EDTA and DTPA, the shoot of Thlaspi caerulescens accumulated more $\mathrm{Zn}$ than the control [21]. Also, EDTA could improve the accumulation of $\mathrm{Pb}$ and $\mathrm{Zn}$ in Chrysanthemum coronarium and Cirsium japonicum [31,32], which had significant correlation with its concentrations [33]. Meanwhile, this study found that EDTA and DTPA enhanced the contents of $\mathrm{Pb} / \mathrm{Zn}$ in root and shoot of ryegrass plant, which was consistent with the research of Wang [34], and increased total $\mathrm{Pb} / \mathrm{Zn}$ accumulation and translocation ratio in ryegrass plant.

Bell [35] and Wenzel [36] reported that metal chelates could enter the root from the endodermis cleft and transfer into plants' stem and leaves. In the marking test of ${ }^{14} \mathrm{C}$-EDTA-Pb, Blaylock [29] found that plants accumulated $\mathrm{Pb}$ more easily with chelators. Salt [6] found that chelation prevented precipitation and absorption of metals, thereby improving metals availability. But a proper concentration of EDTA which induced the accumulation of $\mathrm{Pb}$ was the key, and this may be due to the physiological mechanism of roots which controlled the transmembrane transportation. In this paper, with the same dose, EDTA enhanced total $\mathrm{Pb}$ and $\mathrm{Zn}$ accumulation in shoots more than DTPA, which could be due to its weak chelated ability and poor active ability.

\section{Conclusions}

EDTA and DTPA enhanced the biomass of ryegrass when the dose less than $4 \mathrm{mmol} / \mathrm{kg}$, and enhanced $\mathrm{Zn}$ and $\mathrm{Pb}$ contents in roots and shoots of ryegrass. The total $\mathrm{Pb}$ and $\mathrm{Zn}$ accumulations, translocation ratio and nutrient $(\mathrm{N}$, $\mathrm{P}, \mathrm{K}, \mathrm{Ca}$ and $\mathrm{Mg}$ ) contents in ryegrass had also been en- hanced. The partial correlation analysis showed that DTPA and EDTA didn't significantly correlate with $\mathrm{Pb}$ accumulation in roots and did significantly correlate with $\mathrm{Pb}$ accumulation in shoots of ryegrass, and the correlation between DTPA/EDTA and $\mathrm{Zn}$ accumulation in roots and shoots of ryegrass was significant. Therefore, EDTA and DTPA have great potential to be used for ryegrass to remedy $\mathrm{Pb}$ and $\mathrm{Zn}$ contaminated soil around lead-zinc mining areas, but should be used cautiously because of their environmental risks.

\section{REFERENCES}

[1] Y. H. Wang, Y. L. Zhao, X. J. Chen and S. H. Qi, "Remediation Technology of Contaminated Soils in the Metal Mines," Mining Research and Development, Vol. 27, No. 3, 2007, pp. 66-68.

[2] S. N. Whiting, R. D. Reeves, D. Richards, M. S. Johnson, J. A. Cooke and F. Malaisse, "Research Priorities for Conservation of Metallophyte Biodiversity and their Potential for Restoration and Site Remediation," Restoration Ecology, Vol. 12, No. 1, 2004, pp. 106-116. doi:10.1111/j.1061-2971.2004.00367.x

[3] M. H. Huang and Y. M. Luo, "Land Remedlation and Ecological Restoration of Mined Land," Acta Pedologa Sinica, Vol. 40, No. 2, 2003, pp. 161-169.

[4] J. Cheng and M. H. Wong, "Effects of Earthworm (Pheretima SP.) on Three Sequential Ryegrass Harvests for Remediating Lead/zinc Mine Tailings," International Journal of Phytoremediation, Vol. 10, No. 3, 2008, pp. 173-184. doi:10.1080/15226510801997382

[5] M. A. Kashem, S. Kawai, N. Kikuchi, H. Takahashi, R. Sugawara and B. R. Singh, "Effect of Lherzolite on Chemical Fractions of $\mathrm{Cd}$ and $\mathrm{Zn}$ and Their Uptake by Plants in Contaminated Soil," Water, Air and Soil Pollution, Vol. 207, No. 1-4, 2010, pp. 241-251.

[6] D. E. Salt, M. Baylock, N. P. Kumar, V. Dushenkov, B. D. Ensley, I. Chet and I. Raskin, "Phytoremediation: A Novel Strategy for The Removal of Toxic Metal from The Environment Using Plants," Nature Biotechnology, Vol. 13, No. 5, 1995, pp. 468-474. doi:10.1038/nbt0595-468

[7] Q. Wei, Y. Li and Y. Q. Zu, "Advances in Researching Cultivation Techniques on Hyperaccumulators Phytoremediating The Heavy Metal Contaminated Soil," Journal of Yunnan Agricultural University, Vol. 23, No. 1, 2008, pp. 104-108.

[8] S. J. Shi, K. Zhao and X. M. Chu, "Phytoremediation for Metal Contamination in Soil and Improvement Measures," Journal of Shandong Forestry Science and Technology, Vol. 4, 2006, pp. 66-67.

[9] M. W. H. Evangelou, M. Ebel and A. Schaeffer, "Chelate Assisted Phytoextraction of Heavy Metals from Soil: Effect, Mechanism, Toxicity and Fate of Chelating Agents," Chemosphere, Vol. 68, No. 6, 2007, pp. 989-1003.

[10] C. Garbisu and I. Alkorta, "Phytoextraction: A Cost Effective Plant Based Technology for the Removal of Met- 
als from the Environment," Bioresource Technology, Vol. 77, No. 3, 2002, pp. 229-236. doi:10.1016/S0960-8524(00)00108-5

[11] H. Grčman, Š. Velikonja-Bolta, D. Vodnik, B. Kos and D. Leštan, "EDTA Enhanced Heavy Metal Phytoextraction: Metal Accumulation, Leaching, and Toxicity," Plant and Soil, Vol. 235, No. 1, 2001, pp. 105-114. doi:10.1023/A:1011857303823

[12] J. Japenga, G. F. Koopmans, J. Song and P. F. Römkens, "A Feasibility Test to Estimate The Duration of Phytoextraction of Heavy Metals from Polluted Soils," International Journal of Phytoremediation, Vol. 9, No. 2, 2007, pp. 115-132.

[13] G. F. Koopmans, P. F. A. M. Römkens, J. Song, E. J. M. Temminghoff and J. Japenga, "Predicting The Phytoextraction Duration to Remediate Heavy Metal Contaminated Soils," Water Air and Soil Pollution, Vol. 181, No. 1-4, 2007, pp. 355-371. doi:10.1007/s11270-006-9307-7

[14] E. Meers, F. M. G. Tack and M. G. Verloo, "Degradability of Ethylenediaminedisuccinic Acid (EDDS) in Metal Contaminated Soils: Implications for Its Use Soil Remediation," Chemosphere, Vol. 70, No. 3, 2008, pp. 358-363.

[15] C. L. Luo, Z. G. Shen and X. D. Li, "Plant Uptake and The Leaching of Metals During The Hot EDDS-enhanced Phytoextraction Process," International Journal of Phytoremediation, Vol. 9, No. 3, 2007, pp. 181-196. doi:10.1080/15226510701375986

[16] P. Kidd, J. Barceló, M. P. Bernal, F. Navari-Izzo, C. Poschenrieder, S. Shilev, R. Clemente and C. Monterroso, "Trace Element Behaviour at the Root-Soil Interface: Implications in Phytoremediation," Environmental and Experimental Botany, Vol. 67, No. 1, 2009, pp. 243-259. doi:10.1016/j.envexpbot.2009.06.013

[17] L. Duquène, H. Vandenhove, F. Tack, E. Meers, J. Baeten and J. Wannijn, "Enhanced Phytoextraction of Uranium and Selected Heavy Metals by Indian Mustard and Ryegrass Using Biodegradable Soil Amendments," Science of the Total Environment, Vol. 407, No. 5, 2009, pp. 1496-1505. doi:10.1016/j.scitotenv.2008.10.049

[18] W. H. Xu, H. X. Wang, Z. Y. Wang and Z. T. Xiong, "Response of Hyperaccumulator Ryegrass (Loliurn perenne L.) to Cadmium, Zinc and Their Combined Pollution," Chinese Agricultural Science Bulletin, Vol. 22, No. 6, 2006, pp. 365-368.

[19] F. Lian, S. L. Zhao, M. Teng and L. Duo, “A. Effects of EDTA on Seed Germination and Seeding Growth of Annual Ryegrass," Heilongjiang Animal Science and Veterinary Medicine, Vol. 12, 2007, pp. 62-64.

[20] J. W. Huang, J. Chen and W. R. Berti, "Phytoremediation of Lead-contaminated Soils: Role of Synthetic Chelates in Lead Phytoextraction," Environmental Science and Technology, Vol. 31, No. 3, 1997, pp. 800-805. doi:10.1021/es9604828

[21] D. J. Zhao, "Research of Chelate-induced Technology Applied in Phytoremediation of Heavy Metal Contaminated Soils," Zhongshan University, Zhongshan, 2004.

[22] Y. C. Chen, Z. T. Xiong and S. Y. Dong, "Chemical Be- havior of Cadmium in Purple Soil as Affected by Surfactants and EDTA," Pedosphere, Vol. 16, No. 1, 2006, pp. 91-99.

[23] Y. H. Chen, Z. G. Shen and L. G. Zong, "Effects of EDTA on Pb Accumulation by Seedlings of Two Brassica Juncea Varieties," Research of Environmental Sciences, Vol. 18, No. 1, 2005, pp. 67-70.

[24] Y. F. Fang, Y. Y. Zheng, N. Tang and L. K. Can, "EDTA Enhanced Electroremediation of Lead-Contaminated Soil," Journal of Agro-Environment Science, Vol. 27, No. 2, 2008, pp. 612-616.

[25] H. Zaier, T. Ghnaya, K. Ben Rejeb, A. Lakhdar, S. Rejeb and F. Jemal, "Effects of EDTA on Phytoextraction of Heavy Metals ( $\mathrm{Zn}, \mathrm{Mn}$ and $\mathrm{Pb}$ ) from Sludge-Amended Soil with Brassica napus," Bioresource Technology, Vol. 101, No. 11, 2010, pp. 3978-3983. doi:10.1016/j.biortech.2010.01.035

[26] S. A. Wasay, S. F. Barrington and S. Tokunaga, "Organic Acids to Remediate A Clay Loam Polluted by Heavy Metals," Canadian Agricultural Engineering, Vol. 40, 1998, pp. 9-15.

[27] X. Ke, P. J. Li, Z. Q. Gong, W. Yin and D. Su, “Advances in Flushing Agents Used for Remediation of Heavy Metal-contaminated Soil," Chinese Journal of Ecology, Vol. 23, No. 5, 2004, pp. 145-149.

[28] J. Sun, B. Q. Tie, P. F. Qin, Y. W. Yang, Z. Qian and S. X. Qing, "The Potential of Juncus effuses and Eulaliopsis binata for Phytoremediation of Lead/zinc Mine Tailings Contaminated Soil under the Adjustment of EDTA," Research of Environmental Sciences, Vol. 19, No. 4, 2006, pp. 105-110.

[29] M. J. Baylock, D. E. Salt, S. Dushenkov, O. Zakharova, C. Gussman, Y. Kapulnik, B. D. Ensley and I. Raskin, "Enhanced Accumulation of $\mathrm{Pb}$ in Indian Mustard by Soil-Applied Chelating Agents," Environmental Science \& Technology, Vol. 31 No. 3, 1997, pp. 860-865. doi:10.1021/es960552a

[30] W. Xu, W. Li, J. He, S. Balwant and Z. Xiong, "Effects of Insoluble Zn, Cd, and EDTA on The Growth, Activities of Antioxidant Enzymes and Uptake of $\mathrm{Zn}$ and $\mathrm{Cd}$ in Vetiveria zizanioides," Journal of Environmental Sciences, Vol. 21, No. 2, 2009, pp. 186-192.

[31] L. L. Chun, G. S. Zhen, Q. L. Lai and G. L. Xian, "EDDS and EDTA-Enhanced Phytoextraction of Metals from Artificially Contaminated Soil and Residual Effects of Chelant Compounds," Environmental Pollution, Vol. 144, No. 3, 2006, pp. 862-871. doi:10.1016/j.envpol.2006.02.012

[32] J. Hernández-Allica, C. Garbisua, O. Barrutiab and J. M. Becerril, "EDTA-Induced Heavy Metal Accumulation and Phytotoxicity in Cardoon Plants," Environmental and Experimental Botany, Vol. 60, No. 1, 2007, pp. 26-32.

[33] L. D. Liu, J. L. Shu and Z. K. Yang, "Effects of Chitosan and EDTA on Lead Desorption in Pb Contaminated Soil," Journal of Agro-environment Science, Vol. 25, No. 2, 2006. pp. 345-348.

[34] H. Q. Wang, S. J. Lu and Y. J. Chen, "On The Applica- 
tion of Chelate-induced and Transgenic Technique in Phytoremediation of Polluted Soils," Earth Science Frontiers, Vol. 12, No. S, 2005, pp. 36-42.

[35] P. E. Bell, R. L. Chaney and J. S. Angle, "Free Metal Activity and Total Metal Concentrations as Indices of Micronutrient Availability to Barley [Hordeum vulgare (L.) 'Klages']," Plant and Soil, Vol. 130, No. 1-2, 1991, pp. 51-62. doi:10.1007/BF00011855

[36] W. W. Wenzel, R. Unterbrunner, P. Sommer and P. Sacco, "Chelate-Assisted Phytoextraction Using Canola (Brassica napus L.) Inoutdoors Pot and Lysimeter Experiments," Plant and Soil, Vol. 249, 2003, pp. 83-96. doi:10.1023/A:1022516929239 